\title{
PRAGMATYCZNE ASPEKTY LINGWISTYKI INTERKULTUROWEJ (ZE SZCZEGÓLNYM UWZGLĘDNIENIEM STOSUNKÓW POLSKO-WSCHODNIOSEOWIAŃSKICH)
}

\author{
PRAGMATIC ASPECTS OF INTERCULTURAL LINGUISTICS \\ (WITH SPECIAL REGARD TO POLISH-EAST SLAVIC RELATIONS)
}

\author{
ALEKSANDER KIKLEWICZ
}

\begin{abstract}
A cultural situation is defined as a group of individuals (usually organized groups of entities), functional systems (such as politics, science, religion, sports, the mass media, education, the military, etc.), conceptual systems (including systems of values) as well as forms in which they are manifested, and of relevant environments - ecological, economic, existential ones, etc. (i.e. the stage of events). The author presents a semiotic model of discourse which is founded on four categories: pragmatics, semantics, the form/structure of a message and the context (of a given speech act). The author shows (mainly based on the example of the Eastern European cultural area) the volatility of the relationship between these categories depending on the type of cultural situations. Separate sections describe the pragmatic parameters of a cultural situation: the intensity of the pragmatic/ persuasive function as well as the degree of expressiveness, ceremoniousness, politeness and stylistic differentiation of language and the monologism vs. dialogism dichotomy.
\end{abstract}

Aleksander Kiklewicz, Uniwersytet Warmińsko-Mazurski w Olsztynie, Olsztyn - Polska.

\section{Wstęp}

Przedmiotem niniejszego artykułu jest zastosowanie funkcjonalnych aspektów znaku, a zwłaszcza aspektu pragmatycznego, do opisu procesów i mechanizmów komunikacji międzykulturowej. Z semiotycznego punktu wyodrębnia się cztery kategorie właściwości komunikatów: pragmatykę, semantykę, formę/strukturę oraz kontekst. W zależności od warunków komunikacji układ tych czterech aspektów znaku ulega modyfikacjom ${ }^{1}$, co ma szczególne znaczenie dla komunikacji międzykulturowej, ponieważ w tym przypadku partnerzy interakcji reprezentują odmienne formacje kulturowe,

1 Zob.: A. K i k l e w i c z, Modelowanie parametryczne przestrzeni komunikacyjnej (aspekty stylistyczne), [w:] Teorie komunikacji i mediów, pod red. M. Graszewicza, J. Jastrzębskiego, t. 2, Wrocław 2010, s. 61 i n. 
warunkujące odmienne profilowanie znaku - jako wartości przeważnie semantycznej, bądź przeważnie pragmatycznej (praktycznej), bądź formalnej (materialnej) itd. Na skutek oddziaływania czynnika kulturowego w strukturze dyskursu może zostać wyeksponowany jakiś jeden aspekt albo grupa powiązanych ze sobą aspektów.

Pod tym względem na szczególną uwagę zasługuje $n$ a s t a w i e n i e pragmacentryczne jako cecha charakterystyczna współczesnej kultury postmodernizmu (zauważalna nie tylko w mediach - reklamie, dziennikarstwie, public relations, lecz także $\mathrm{w}$ dyskursach akademickich czy edukacyjnych). Pragmatyzm w komunikacji uważa się także za cechę kultury Zachodu, szczególnie w jej opozycji do kultury Wschodu².

\section{Pragmatyka komunikacji międzykulturowej}

Każde zniekształcenie zoptymalizowanego układu czterech aspektów komunikacji w większym lub mniejszym stopniu warunkuje skupienie uwagi na aspekcie pragmatycznym, w szczególności wzmacnia ekspresję wypowiedzi, jej funkcję sprawczą. Istnieją ponadto takie aspekty sytuacji kulturowej, które bezpośrednio należą do sfery pragmatyki. Najczęściej jest rozpatrywany jeden $\mathrm{z}$ nich: treść i pozycjonowanie aktów mowy, na co na przykład wskazuje obszerne studium A. Wierzbickiej ${ }^{3}$. W kolejnych punktach omówię inne aspekty pragmatyczne komunikacji międzykulturowej: stopień ekspresywności wypowiedzi, stopień zrytualizowania zachowań komunikacyjnych, stopień uprzejmości, a także monologowość/ dialogowość.

\subsection{Stopień ekspresywności zachowań komunikacyjnych}

W komunikacji międzyludzkiej, jak pisze Z. Nęcki, obowiązuje r e g u$\nmid$ a e k s p r e s y j n o ś c i, zgodnie z którą należy dążyć do „nadawania możliwie osobistego i emocjonalnego tonu wypowiadania się, tak by odbiorca wiedział, jaki jest stosunek nadawcy do mówionego tekstu"4. Choć wymóg ekspresyjności ma charakter ogólny, to jednak jego realizacja zależy od warunków komunikacji, a także uczestniczących w niej podmiotów. Na przykład zwrócono uwagę, że komunikacyjnym zachowaniom przedstawicieli niższych warstw społecznych jest właściwa konkretność i większy stopień kategoryczności wypowiedzi ${ }^{5}$. Rosyjski pisarz Wsiewołod Iwanow, autor kilku powieści na temat rewolucji październikowej 1917 roku,

2 Zob.: Б.В. Г р и г о р ь е в, В.И. Ч у м а к о в а, Межкультурные коммуникациии, Санкт-Петербург 2008, s. 300.

${ }^{3}$ A. W i e r z b i c k a, Jezyk-umyst - kultura, Warszawa 1999, s. 228 i n.

4 Z. N ę c k i, Komunikacja międzyludzka, Kraków 2000, s. 130.

5 Z. N ę c k i, op. cit., s. 48; J. B o b r y k, Jak tworzyć rozmowę. Skuteczność rozmowy, Warszawa 1995, s. 28 i n. 
podkreślał, że rewolucjoniści mówią nader głośno i sugestywnie, dążąc w ten sposób do dominacji, ale pokonując też pewne kompleksy.

Za sprawą tych zróżnicowań $\mathrm{w}$ komunikacji przedstawicieli różnych klas powstają zakłócenia, $\mathrm{w}$ tym szczególne, nieprzewidywane reakcje partnerów, jak np. we fragmencie sztuki Jerzego Szaniawskiego Dwa teatry:

Matka. Wy tam w miastach wolicie się łajdaczyć niż mieć dzieci.

Pani (ubawiona i nie urażona). Ha, ha. Pani mocno się wyraża.

Jak widzimy, matka jako przedstawicielka niższej warstwy społecznej (jest wdową po leśniczym) „wyraża się mocno”, co jednak nie wywołuje u mieszkającej w mieście Pani (nauczycielki z zawodu) reakcji odwetowej, gdyż jej zachowanie $\mathrm{w}$ większym stopniu jest podporządkowane innej regule komunikacji - uprzejmości. Zgodnie z definicją Nęckiego polega ona na konstruowaniu wypowiedzi w taki sposób, aby były one "możliwe do zaakceptowania przez partnera" i nie wywoływały "nieprzyjemnych stanów uczuciowych"6.

Stopień ekspresyjności wypowiedzi jest odmienny w różnych sytuacjach funkcjonalnych. Tak więc we współczesnych dyskursach dziennikarskich $\mathrm{w}$ porównaniu $\mathrm{z}$ dziennikarstwem tradycyjnym znacznie wzrosła ekspresja przekazu - niewątpliwie pod wpływem "języka publicznego" ( $w$ terminologii B. Bernsteina), a także (perswazyjnych w swej istocie) tekstów reklamy.

R.R. Gesteland zwrócił uwagę na to, że nastawienie na eksponowanie stanów emocjonalnych jest odmienne $\mathrm{w}$ różnych kulturach narodowych ${ }^{7}$. Wyodrębniając kultury ekspresyjne i powściągliwe, wspomniany badacz pisze, że różni je nie tylko stopień akceptowania zachowań ekspresywnych, lecz także formy wyrażania ekspresji - werbalne lub niewerbalne. W kulturach pierwszego typu szczególnie dużą rolę odgrywa przekaz niewerbalny, zwłaszcza tzw. mowa ciała oraz specyficzna proksemika, co u przedstawicieli kultur drugiego typu może budzić niezrozumienie. Do obszaru kultur ekspresyjnych należą kraje śródziemnomorskie 8 i latynoamerykańskie, natomiast do obszaru kultur powściągliwych - kraje azjatyckie (przede wszystkim Azji Wschodniej i Południowo-Wschodniej), a w Europie - kraje skandynawskie i germańskie.

${ }^{6}$ Z. N ę c k i, op. cit., s. 130.

7 R.R. G e s t e 1 a $n$ d, op. cit.

${ }^{8}$ L.N. Kolesnikowa pisze,że w kulturze arabskiej emocjonalny styl wypowiadania się jest uważany za normę, a wysoka siła głosu jest odbierana jako znak szczerości mówiącego; zob. Л.Н. К о л е с н и к о в а, Профессиональные требования к преподавателю русского языка как иностранного, „Вестник Московского университета” 2010, № 19/1, s. 126. 
Porównując kulturę polską i rosyjską, należy stwierdzić, że zachowaniom Rosjan właściwa jest większa ekspresyjność (czy też emocjonalność) ${ }^{9}$. Opisywana tu różnica dwóch kultur znajduje wyraz w odmiennej akceptacji zachowań dewiacyjnych, mających cechy in fanty li z m u k o m un i k a c y j n e g o, karnawalizacji, gry językowej czy też tego, co w języku rosyjskim określa się jako озорство. Wyraz ten na język polski tłumaczy się jako 'łobuzerstwo, zgorszenie, wybryki', choć tłumaczenie nie oddaje istotnej różnicy konotacji kulturowych: rosyjski wyraz, w odróżnieniu od polskich odpowiedników, ma tylko lekkie nacechowanie negatywne, ale może być odbierany też całkiem pozytywnie. W rosyjskich tekstach kultury озорник (czyli dosłownie 'łobuz, psotnik') to raczej żartowniś, wesołek, który żyje w zgodzie z naturą i potrafi zachować humor w najtrudniejszych sytuacjach - por. przykład dieda Szczukara z powieści Michaiła Szołochowa Zaorany ugór czy przykład Sieni Maliny - postaci z bajek Siemiona Pisachowa.

W kulturze rosyjskiej ponadto występuje fenomen określany jako cmaрушка-веселушка, czyli 'babka-żartownisia'. Oczywiście nie można twierdzić, że obraz ten w ogóle nie jest spotykany u Polaków - wystarczy powołać się na przykład Hanki Bielickiej, jednak w Polsce kojarzy się on głównie ze sferą kabaretu, estrady, podczas gdy w Rosji obejmuje rozmaite sfery komunikacji publicznej: literaturę, reklamę, a nawet naukę. Jednym z takich przykładów jest szeroko znana w Rosji babcia Szapoklak - bohaterka filmu rysunkowego dla dzieci według scenariusza Edwarda Uspienskiego. Za inny przykład może posłużyć fenomen prof. Ludmiły A. Iwaszko z Sankt Petersburga, która na konferencji naukowej „Frazeologia a językowe obrazy świata przełomu wieków" w 2006 roku na Uniwersytecie Opolskim prowadziła jedną z sekcji. Wszyscy zgłoszeni do udziału w tej sekcji uczestnicy konferencji z Polski byli zaskoczeni frywolnym (obfitującym w żarty językowe) stylem prowadzenia obrad tej pani, a zwłaszcza tym, że w momencie, gdy wyznaczony na wygłoszenie referatu czas zbliżał się do wyczerpania, prof. Iwaszko kilkakrotnie wydawała głośny dźwięk: „Kukuryku!!!” Taka maniera zachowań w dyskursie akademickim Polakom (szczególnie jeżeli chodzi o kobiety) jest zupełnie obca, natomiast Rosjan bawi, ale wcale nie razi.

\subsection{Stopień ceremonialności zachowań komunikacyjnych}

W komunikacji międzyludzkiej występują dwa typy zachowań językowych: aktywne, celowe, inwencjonalne oraz reaktywne, skutkowe, konwencjonalne. W różnych sytuacjach kulturowych ich realizacja ulega jednak zmianom. Zróżnicowanie to występuje przede wszystkim w różnych

9 И.А. С т е р н и н, Основные особенности русской коммуникативной культуры, [w:] Человек, сознание, коммуникация, интернет, под ред. Л. Шипелевич, Warszawa 2004, s. 34. 
systemach funkcyjnych: o ile w środowisku militarnym czy administracyjnym obowiązuje hierarchia stanowisk, pozycji społecznych oraz nadrzędnie ustalony system etykiety językowej, o tyle np. w środowisku komunikacji potocznej (a szczególnie jeżeli chodzi o zjawiska undergroundowe) rytualność formalna (w ujęciu E. Berne'a) jest czymś marginalnym, a czasem nawet celowo lekceważonym, unikanym.

Większy udział zachowań konwencjonalnych wyróżnia także kulturę wiejską na tle kultury miejskiej. Postępująca urbanizacja przyczyniła się do stopniowej regresji w sferze funkcjonowania wielu dyskursów kultury ludowej, np. takich jak przysłowia, zagadki, pieśni (okolicznościowe, biesiadne, związane z pracą i in.). Odwrotnie - kulturze wiejskiej jest właściwa mniejsza funkcjonalność rytuałów formalnych. Tym A. Gura tłumaczy unikanie konfliktów w tradycyjnej kulturze chłopskiej Rosjan ${ }^{10}$.

Sytuacje kulturowe mogą się różnić pod względem ideologicznym i historycznym. Na przykład w krajach objętych systemem totalitarnym dominuje komunikacja rytualna, a mianowicie ścisła reglamentacja sytuacji, sfer i obszarów komunikacji językowej, a także stosowanych w nich form języka, w szczególności słów-pasożytów, frazeologizmów, tekstów rutynowych (np. rytualnych zwrotów życzących), skrótowców ${ }^{11}$. O języku totalitaryzmu J. Warchala pisze, że "postępowała atrofia funkcji informacyjnej na rzecz wypełnienia funkcji rytualnej tekstów, rozrost czystej formuliczności i pustego etykietowania"12.

Gesteland pisze o zróżnicowaniu pod względem ceremonialności/nieceremonialności na poziomie kultur narodowych ${ }^{13}$. Na przykład stopień ceremonialności zachowań komunikacyjnych w krajach Wschodu jest wyższy niż w krajach Europy Zachodniej, w Europie jest wyższy niż w Australii czy Stanach Zjednoczonych, w Niemczech jest wyższy niż w Polsce, a w Polsce jest wyższy niż w Rosji czy na Ukrainie.

Swego czasu, przebywając w Niemczech jako stypendysta Fundacji Aleksandra Humboldta, zwróciłem uwagę na pracowników niemieckiej poczty, którzy zwracali się do siebie oficjalnie: Herr Zeiske! Frau Lindenbauer! itp. W Polsce taka sytuacja jest raczej nietypowa, gdyż w tym środowisku kulturowym zwykle posługuje się formą familiarną - samym imieniem

10 А. Г у р а, О конфликтных ситуациях в традиционной крестьянской культуре, [w:] Семиотика скандала, под ред. Н. Букс, Париж-Москва 2008, s. 92 i n.

$11 \mathrm{~J}$. B r a 1 c z y k, O jezyku polskiej propagandy politycznej lat siedemdziesiatych, Warszawa 2001, s. 46; K. O ż ó g, Ewolucja językowych rytualizmów społecznych i towarzyskich (od roku 1945 do chwili obecnej), [w:] Rytualizacja w komunikacji społecznej i interkulturowej, pod red. J. Mazura, Lublin 2004, s. 28.

12 J. W a r c h a l a, Kategoria potoczności w języku, Katowice 2003, s. 145.

${ }_{13}$ R.R. G e s t e 1 a n d, op. cit. Zob. także: Б.В. Г р и г о р ь е в, В.И. Ч у м а ко в а, op. cit., s. 92. 
(bez dodatków), które często występuje w formie zdrobniałej: Beatko! Andrzej$k u$ ! itd. (A. Wierzbicka widzi w tych formach wyraz większej spontaniczności czy też serdeczności kultury polskiej w porównaniu z kulturą anglosaską $\left.{ }^{14}\right)$. W podobny sposób I.A. Sternin pisze, że cechą charakterystyczną komunikacyjnego stylu Rosjan (w zestawieniu z mieszkańcami Europy Zachodniej) jest dążenie do komunikacji nieformalnej - inaczej Sternin nazywa to demokratyzmem komunikacyjnym: Rosjanie preferują w komunikacji parytet - niezależnie od stopnia znajomości/nieznajomości partnerów, dlatego często unika się ceremonii, etykiety językowej, demonstruje się otwartość, poufność konwersacji15.

Zróżnicowania pod względem ceremonialności znajdują wyraz w komunikacji międzykulturowej. Typowe dla przedstawicieli kultury nieceremonialnej zwracanie się po imieniu czy wyciąganie pierwszemu ręki przy powitaniu ze starszą osobą jest odbierane przed przedstawiciela kultury ceremonialnej jako niegrzeczne, a nawet chamskie. Za inny przykład może posłużyć nieumiejętność przedstawicieli kultur nieceremonialnych $\mathrm{w}$ zakresie posługiwania się stylem oficjalno-urzędowym. Dla kultury rosyjskiej nie jest charakterystyczne zastosowanie $\mathrm{w}$ sferze komunikacji administracyjnej elementów potocznych (o tzw. funkcji fatycznej) - informacyjne i proceduralne (w tym ekspresywne) wątki przekazu są zasadniczo odseparowane. Inaczej jest $w$ kulturze japońskiej ${ }^{16}$ : wypowiedzi oficjalne i nieoficjalne (osobiste) tu się swobodnie przeplatają, nie obowiązuje monotoniczność stylistyczna. W związku z tym D.B. Gudkow przytacza fragment oficjalnego listu japońskiego korespondenta do rosyjskiego adresata, którego stylistyka jest niezwykła z punktu widzenia europejskiej kultury (nie tylko rosyjskiej, ale także np. polskiej) ${ }^{17}$ :

Szanowny Panie Ministrze! Nadeszła jesień. Mamy nadzieję, że czuje się Pan dobrze. Z głęboką satysfakcją pragnę powiadomić Pana, że pani N., lektor języka rosyjskiego, delegowana przez kierowane przez Pana Ministerstwo, szczęśliwie dojechała i rozpoczęła pracę na naszym Uniwersytecie. Mimo chłodnego sezonu pani N. czuje się dobrze, co nas bardzo cieszy, dlatego śpieszę ucieszyć Pana tym faktem. Pragnę podziękować Panu oraz pracownikom Ministerstwa, szczególnie Panu X., który zajmuje się współpracą z naszym Uniwersytetem, za przybycie pani N. we właściwym czasie. Wyrażam także nadzieję na przychylną uwagę Pana do nas w przyszłości.

Z głębokim szacunkiem Rektor Uniwersytetu (podpis).

14 A. W i e r z b i c k a, op. cit., s. 215.

15 И.А. С т е р н и н, ор. cit., s. 35.

${ }^{16} \mathrm{Mimo}$ faktu, że w języku japońskim istnieją formy gramatyczne (np. w systemie zaimków), przyporządkowane różnym społecznym statusom rozmówców.

17 Д.Б. Г у д к о в, Теория и практика межкультурной коммуникации, Москва 2003, s. 73. 


\subsection{Stopień uprzejmości}

W punkcie 2.1. była mowa o obowiązującej w komunikacji międzyludzkiej regule uprzejmości (zob. „tact maxim” w teorii G. Leecha ${ }^{18}$ ). Zasada funkcjonowania tej reguły nie różni się od innych: w różnych sytuacjach kulturowych zmienia się stopień jej przestrzegania, co znajduje wyraz w nawykach etykietalnych przedstawicieli wspólnot kulturowych. Pisałem już o większym stopniu honoratywności zachowań językowych Polaków $\mathrm{w}$ porównaniu $\mathrm{z}$ Rosjanami ${ }^{19}$. W języku polskim $\mathrm{w}$ celu podkreślania oficjalno-uprzejmego charakteru czynności językowej (w szczególności takiego aktu mowy jak prośba) są m.in. wykorzystywane czasowniki optatywne, por.:

Bardzo proszę Pana Profesora, żeby Pan zechciał zgodzić się na ten termin.

Pani zechce odpowiedzieć na moje pytanie.

Czy jeszcze Pan zechce odpowiedzieć?

Dla języka rosyjskiego takie używanie czasowników woluntatywnych, szczególnie podkreślające uprzejmy charakter prośby, nie jest charakterystyczne, dlatego rosyjskie odpowiedniki przytoczonych wyżej wypowiedzeń nie posiadają takiego natężenia kategorii honoratywności, jak wypowiedzenia polskie:

Я очень Вас прошу, чтобы Вы согласились с этим сроком.

Ответьте, пожалуйста, на мой вопрос. //Будьте любезны, ответьте на мой вопрос.

Может быть, Вы еще хотите ответить?

W niemieckiej etykiecie językowej, jak można sądzić, obowiązuje jeszcze większy niż w Polsce stopień uprzejmości. Za przykład może posłużyć zwrot klientki do kasjerki (przykład pochodzi z autentycznej sytuacji, której byłem świadkiem na Uniwersytecie w Poczdamie):

Wir möchten gerne Geld erhalten.

Przysłówek gerne można tu potraktować jako operator honoratywności, gdyż jego funkcja polega na przekazaniu informacji o satysfakcji klienta, która nastąpi po dokonaniu transakcji. W tym przypadku mamy do czynienia z prośbą ('Proszę o wypłatę pieniędzy'), która jest połączona z podziękowaniem ('Z góry dziękuję za przysługę'), a może także z deklaracją ('Przyznaję, że korzystanie z Pani usług sprawia mi przyjemność'). Posługując się terminologią prawniczą, prośby i deklaracje takiego typu można kwalifikować jako czynności wyprzedzające, a więc niepozbawione elementów rytualności. Gdybyśmy przetłumaczyli powyższe wypo-

18 G. L e e c h, Principles of Pragmatics, London 1983.

${ }^{19} \mathrm{~A}$. K i k l e w i c z, Funkcja stylistyczna wypowiedzi w perspektywie lingwistyki porównawczej, "Stylistyka” 2011, nr XX, s. 33. 
wiedzenie niemieckie na język polski czy rosyjski dosłownie, brzmiałoby ono sztucznie:

? Chcielibyśmy chętnie / z przyjemnością / z radością otrzymać pieniądze.

? Мы бы хотели с удовольствием получить деньги.

$\mathrm{W}$ autentycznej wersji polskiej czy rosyjskiej z odpowiednika przysłówka gerne należałoby zrezygnować.

W opozycji do kultur o wysokim stopniu uprzejmości (czy też serdeczności, jak to określa Wierzbicka) stoją kultury podobne do rosyjskiej, gdzie brak życzliwości w stosunku do partnera komunikacyjnego (czasem graniczący z ordynarnością) oraz bezkompromisowość zachowań są często spotykanym zjawiskiem ${ }^{20}$. Badacze piszą, że niegrzeczność, grubiańskość jest oficjalnie potępiana przez rosyjskie normy kulturowe, lecz $\mathrm{w}$ praktyce komunikacyjnej szeroko kultywuje się ją $\mathrm{w}$ różnych sferach: oficjalnej i nieoficjalnej, w relacjach towarzyskich, rodzinnych, zawodowych i in. ${ }^{21}$ Sternin pisze o pokrewnej cesze rosyjskiej kultury komunikacyjnej - unikaniu uśmiechu: Rosjanie nie mają zwyczaju uśmiechać się do ludzi nieznajomych, nie odpowiadają uśmiechem na uśmiech. Uśmiech jest traktowany w Rosji jako wyraz osobistej sympatii dla konkretnego człowieka ${ }^{22}$.

Różnice kulturowe w zakresie kategorii uprzejmości mogą stawać się przyczyną nieporozumień, a nawet konfliktów w komunikacji międzykulturowej. Rozważmy następujący przykład23:

Rosjanin: Ты очень хорошо говоришь по-русски.

Chińczyk: Нет! Вообще-то я плохо говорю.

Rosjanin daje pozytywną ocenę jakości mówienia Chińczyka po rosyjsku, ale ten, posługując się własnymi normami kulturowymi, uważa, że przede wszystkim należy być skromnym, w ten sposób manifestując swoją grzeczność wobec partnera ${ }^{24}$. Jak widzimy, w kulturze chińskiej grzeczność jest oparta na pojęciu skromności, podczas gdy w kulturze rosyjskiej - na pojęciu zgody. Dlatego Chińczyk i Rosjanin opierają się na różnych progra-

${ }^{20}$ Choć niektórzy badacze piszą o dobroduszności, poczciwości Rosjan, zob.: Л.H. Кo л е с н и к о в а, op. cit., s. 124.

${ }^{21}$ И.А. С т е р н и н, ор. cit., s. 36; Ю.А. А р я м о в а, Анализ интерпретации англофонами коммуникативного поведения российских сотрудников в сфере обслуживания авиапассажиров, „Вестник МГОУ” 2010, № 2, s. 124-128.

22 И.А. С т е р н и н, op. cit., s. 36.

${ }^{23} \mathrm{Yu} \mathrm{J}$ i a $\mathrm{m}$ i n, Factors of communicative failures of the Chinese students at their training to Russian, [http://www.emissia.org/offline/2011/1609.htm] (dostęp 2012).

${ }^{24}$ L.N. K o 1 e s n i k o w a pisze, że na tle Rosjan studenci z Chin wyróżniają się nadgorliwością w zakresie uprzejmości językowej, np. po zakończeniu zajęć bardzo długo żegnają się z wykładowcą, mogą nawet odprowadzić go i kontynuować pożegnanie już na ulicy; zob. Л.Н. К о л е с н и к о в а, ор. cit., s. 128. 
mach zachowawczych, co powoduje nieporozumienie: Rosjanin nie odczytuje $\mathrm{w}$ replice Chińczyka nastawienia uprzejmego i uważa, że jego partner komunikacyjny wyraża $\mathrm{w}$ ten sposób niezgodę $\mathrm{z}$ jego repliką. Skutkuje to zakończeniem rozmowy.

\subsection{Monologowość vs. dialogowość}

W zależności od celów i warunków komunikacji zachowania językowe realizują się w formie dialogu lub monologu. Aktywność stosowania tych form zależy od sytuacji kulturowej. Ogólnie rzecz biorąc, monolog stanowi w pewnym sensie produkt ewolucji kulturowej - wskazuje na to fakt, że komunikacja $\mathrm{w}$ świecie zwierząt, a także $\mathrm{w}$ społeczeństwach pierwotnych przeważnie nosi charakter monologowy. Jako jeden z pierwszych zwrócił na to uwagę rosyjski językoznawca L.W. Szczerba, który w pierwszej połowie XX w. badał dialekty łużyckie. Obserwując zachowania językowe wieśniaków, przekonał się, że przeważnie posługują się oni mową dialogową - monologi występują bardzo rzadko ${ }^{25}$. Szczerba w związku z tym pisał, że monolog stanowi w pewnym stopniu sztuczną formę realizacji języka, którego naturalne funkcjonowanie objawia się przede wszystkim w dialogu. Sam L. P. Jakubinskij pisał, że dialogowa forma zachowań językowych najbardziej odpowiada reflektorowej istocie działalności psychicznej człowieka, a więc jest niejako zakodowana w jego naturze biologicznej26.

Na rozwój monologowości pozytywnie wpływa piśmiennictwo, a także rozwój tych sfer działalności społecznej, które są oparte na wymianie tekstów pisanych, np. sfery urzędowej. Dlatego kultury o bogatej tradycji piśmiennictwa dysponują szerszym rejestrem dyskursów (czy też gatunków) monologowych, choć zależność ta nie jest bezpośrednia, gdyż na dialogowy lub monologowy charakter zachowań językowych wpływają też inne czynniki, np. stopień ceremonialności. Za przykład może posłużyć współczesna kultura kazachska. Mimo że piśmiennictwo kazachskie (w jego współczesnym kształcie) powstało dopiero w XIX w., co mogło przyczynić się do dominującej orientacji na dialog $w$ komunikacji językowej, to jednak w rzeczywistości jest wręcz inaczej: każdy, kto po raz pierwszy styka się z tą kulturą narodową, jest zaskoczony notoryczną skłonnością Kazachów do różnego rodzaju wystąpień, przemówien, wykładów. Przedstawiciele tego narodu uwielbiają np. wygłaszać t o a s t y - niektóre z nich trwają dziesiątki minut, nawet do pół godziny! W telewizji Kazachstanu jest bardzo rozpowszechniony gatunek talk show - jednak w swoistej modyfikacji: goście w studiu chętnie zabierają głos, mówią długo i w bardzo

25 Л.П. Я к у б и н с к и й, Язык и его функционирование. Избранные работы, Москва 1986, s. 31 i n.

26 Ibidem, s. 32. 
spokojnej, "domowej” manierze. Zjawisko to można tłumaczyć wysokim stopniem ceremonialności kultury kazachskiej, w którą zachowania monologowe (czyli swoista kompensacja braku tradycji piśmienniczej) są „wmontowane" jako jej naturalny, nieodłączny element.

\subsection{Stopień stylistycznej dyferencjacji języka}

Każda sytuacja kulturowa dysponuje określonym zespołem systemów funkcyjnych (w terminologii M. Fleischera), którym są przyporządkowane style funkcjonalne języka. Im bardziej złożony charakter ma występujący w społeczeństwie system kultury, tym większa jest liczba stylów, stopień ich zróżnicowania (W.W. Winogradow pisał o zmienności zespołu stylów w różnych epokach rozwoju języka narodowego ${ }^{27}$ ). Zależy to ponadto od długości tradycji piśmiennictwa: najbardziej odczuwalna różnica między obszarem komunikacji oficjalnej, pisanej a obszarem ustnej komunikacji codziennej, między normą a uzusem zachodzi w tych krajach, w których literatura pisana istnieje od dawna, np. w Czechach, gdzie język pisany („,spisovná čeština”) i język mówiony („,obecná čeština”) zawierają częściowo odmienne zasoby jednostek leksykalnych, różniące się systemy fleksyjne, a nawet fonetyczne. W języku polskim czy rosyjskim dystans między normą a uzusem nie jest tak spotęgowany, ale i tu zachodzi różnica: dla kultury rosyjskiej jest charakterystyczna większa specjalizacja stylu naukowego, dlatego w opinii Polaków niektóre rosyjskie teksty naukowe są nader skomplikowane, manieryczne, nieczytelne ${ }^{28}$.

$\mathrm{W}$ kulturach o niedawnej tradycji piśmiennictwa (powstałej $\mathrm{w}$ drugiej połowie XIX w. czy w XX w.) granica między językiem komunikacji oficjalnej a językiem komunikacji potocznej, a także między normą literacką a dialektem jest rozmyta. Taki charakter miał język pierwszych wydań "Naszej Niwy" - białoruskiej gazety wydawanej od 1906 r. W tekstach informacyjnych i publicystycznych występuje wiele elementów stylu potocznego, np. wyrazy deminutywne зямелька (zdrobnienie od зямля 'zіетіа'), вестачка 'nowinka', кароу̃ка 'krówka' (Каб кароујка давала шмат добрага малака - Ażeby krówka dawata dużo dobrego mleka), uaлabeuaк 'człowieczek' i in. Ponieważ nie powstał wówczas jeszcze odrębny styl reklamowy, w tekstach reklamy używało się języka ogólnego i częściowo języka potocznego - o niskim stopniu perswazyjności, por. opublikowaną w "Naszej Niwie" w 1909 r. reklamę sierpów i kos:

Хто хочэ зарабіць крыху грошы і разам зрабіць добрую прыслугу суседзям, той нехай займаецца прадажай слаӱных дабратой сярпоў літоўскіх і кос стырыйскіх (Аўстрыяцкіх). Хто хочэ мець каталёг з цэнамі, той нехай аб гэтым на-

27 В.В. В и н о г р а д о в, Проблемы русской стилистики, Москва 1981, s. 23.

28 Zob.: A. K i k l e w i c z, Funkcja stylistyczna wypowiedzi..., op. cit., s. 29. 
пішэ у склад - вышлюць дарма. [Tłumaczenie: Kto chce zarobić trochę pieniędzy i wyświadczyć dobrą przysługę sąsiadom, niech się zajmie sprzedażą słynących ze swej niezawodności sierpów litewskich oraz kos austriackich. Kto chce mieć kata$\log$ z cenami, niech napisze o tym - wyślemy za darmo].

Stylistyczne zróżnicowanie języków znajduje wyraz w zjawisku $1 \mathrm{uk}$ f u n k c j o n a l n y c h. Polega ono na tym, że przyporządkowane określonemu stylowi formy językowe nie znajdują odpowiedników w innym języku (zwykle biedniejszym stylistycznie). Taką sytuację można było obserwować na Białorusi w latach 90. XX w., po uzyskaniu przez ten kraj niepodległości. Wówczas powstała konieczność stworzenia terminologii naukowo-technicznej, która dotychczas istniała w języku rosyjskim. Terminy zaczęto tworzyć na bazie już istniejących rosyjskich, jednak wiele prób było nieudanych. Ponieważ styl naukowo-techniczny w języku białoruskim był prawie nieobecny, nowo powstałe wytwory językowe wyglądały niezgrabnie, wywoływały zbyt konkretne, przyziemne konotacje. Rozważmy przykład:

БМП-1, боевая машина пехоты гусеничная плавающая ‘BMP-1, bojowy wóz piechoty, gąsienicowy, pływający'.

Problem tłumaczenia jest w tym, że w białoruszczyźnie odpowiedniki rosyjskich wyrazów funkcjonują w znaczeniu konkretno-przedmiotowym. Ich nowemu, nieskonwencjonalizowanemu zastosowaniu w kontekście literatury naukowo-technicznej towarzyszą cechy semantyki pierwotnej, dlatego w tłumaczeniu dosłownym występuje swoista oscylacja znaczeń - podstawowego i nadanego. Na skutek tego powstaje szczególna, nieprzewidywana przez twórcę terminu ekspresja, która w żaden sposób nie przyczynia się do skutecznego funkcjonowania terminu w literaturze specjalistycznej. Tak więc rosyjski przymiotnik гусеничный 'gąsienicowy' jest utworzony na podstawie rzeczownika гусеница 'gąsienica'. Na język białoruski przetłumaczono go jako гусенічны, co budzi zdumienie, gdyż po białorusku gąsienica brzmi: вусенъ, więc uzasadnione byłoby tłumaczenie: вусенічны. W tеj wersji termin ten we współczesnych tekstach białoruskich jest prawie niespotykany, dlatego że wywołuje u Białorusinów zbyt silne skojarzenia obrazowe z gąsienicą jako istotą żywą.

Komplikację sprawia także imiesłów przymiotnikowy nıabaюuuū 'pływający' - za sprawą tego, że w języku białoruskim formy gramatyczne tego typu prawie nie istnieją (właśnie są uważane za rusycyzmy). W tej sytuacji tłumacz jest skazany na to, żeby zastąpić jeden wyraz całą grupą wyrazową:

БМП-1, баявая машына пяхоты, гусенічная, такая, якая плавае.

Porównując rosyjski oryginał i jego białoruski odpowiednik, nie mamy wątpliwości, jak znacząco różnią się one pod względem sprawności, "giętkości" językowej, a to wszystko za sprawą tego, że dwa systemy językowe nie przystają do siebie $\mathrm{w}$ aspekcie stylistycznym. 
Dialog kultur, o którym często pisze się ostatnio nie tylko $\mathrm{w}$ tekstach publicystycznych, lecz także naukowych, możliwy jest dzięki istnieniu wspólnych obszarów, przynajmniej elementów w systemach wartości obydwu kontrahentów. Nie mniej ważna jest także zgodność reguł zachowań językowych, których przebieg realizuje się w pewnym stopniu niezależnie od systemu języka (czy też języków). Dlatego nawet w przypadku komunikacji międzykulturowej przedstawicieli kultur pokrewnych, np. narodów słowiańskich, szczególne znaczenie ma czynnik pragmalingwistyczny. $\mathrm{Z}$ artykułu wynika, że choć systemy językowe języka polskiego, rosyjskiego czy białoruskiego są zasadniczo podobne (dotyczy to zwłaszcza składni czy słownictwa ogólnego), to jednak w zakresie komunikacji językowej w tych obszarach kulturowych zachodzą istotne różnice. 